\title{
Regions picked as biotech 'winners'
}

Munich. Three regions in Germany emerged last week as winners of a well-orchestrated competition called BioRegio, run by the federal research ministry and intended to promote collaboration in biotechnology between academics and industry.

Jürgen Rüttgers, the research minister, named Munich, the Rhine-Neckar Triangle (including Heidelberg, Ludwigshafen and Mannheim) and Rhineland (including Cologne, Düsseldorf and Aachen) as Germany's 'biotechnology model regions' (see map). Seventeen regions had applied. They were asked to provide realistic and innovative ideas for the development of biotechnology in their regions.

Munich's winning concept focuses on the development of genome-based diagnostic and therapeutic products. Its new venturecapital company, Bayern Kapital, has already attracted DM30 million (US\$20 million) of private investment. Rhineland's concept focuses on both biomedical and plant-breeding products, and its two new venture capital companies have attracted DM110 million.

In the Rhine-Neckar Triangle, banks and large pharmaceutical companies such as Boehringer and BASF have jointly founded the Biotechnologiezentrum (Biotechnology Centre) in Heidelberg to support scientists who want to start businesses. A third of the region's suggested projects involve the Heidelberg-based national German Cancer Research Centre. They include the develop- ment of vector systems for gene therapy and basic research in areas such as AIDS.

When the competition was launched a year ago, academics, industrialists and politicians in Germany rose to the challenge with unprecedented fervour, despite the vagueness of the promised prize. In fact, the prize costs the ministry nothing - or at least only the effort of rearranging its existing budget. The ministry has separated DM30 million per year from its budget for biotechnology over the next five years, and the three winning regions will have 'preferential access' to this money.

The ministry did, however, spend DM1.7 million supporting the expensive application procedures for the competition, with each

\section{- Hamburg}

-Munich region that applied receiving half its costs, up to DM100,000. Most regions worked with international business consultancies such as Ernst and Young (Rhine-Neckar Triangle) and Prognos (Munich). And though the tangible prize is small, the prestige of the title should prove a strong attraction to future investors.

The winning regions clearly reflect the current concentration of biotechnological expertise in south and west Germany. Nevertheless, Jena, the east German centre for optics research, was given a 'special merit' by the jury for its plans to create from scratch an environment for biotechnological research.

Peter Radunski, research minister for Berlin, which, with east Germany's Brandenburg, was placed fourth in the competition, noted with regret that "the jury of the BioRegio competition made conventional decisions".

Losers in the competition have clearly benefited from the contacts made when developing their applications. But Rüttgers' optimistic claim that there are no real losers rings a little hollow. The earmarking of some of the ministry's research funds for competition winners reduces the size of the remaining pot for which all German biotechnologists can apply. "This will clearly disadvantage other regions," says Harald zur Hausen, director of the German National Cancer Centre (DKFZ).

Quirin Schiermeier \& Alison Abbott

\section{European convention allows use of human embryos}

Munich. An international convention permitting the use of human embryos for research - but forbidding their creation for such purposes - was adopted last week by the Council of Europe, an intergovernmental body to which 40 states belong.

The Convention on Human Rights and Biomedicine, which sets out a legal framework in which genetic research can be carried out on humans, also forbids germ-line therapy.

But Germany, Poland and Belgium abstained from voting for the convention because it does not impose a total ban on embryo research, and because it also allows research in certain circumstances to be carried out on humans unable to give consent, such as children, the mentally handicapped and patients in a coma.

Failure to reach a consensus on these issues was largely responsible for the rejection of the first draft of the convention by the council's parliamentary assembly two years ago (see Nature 371,643 ; 1994).

The revised document jettisons some of the original controversial clauses, such as that forbidding research on embryos more than 14 days old - which some argued gave implicit approval to research on embryos before 14 days. The convention now merely states that "where the law allows research on embryos in vitro, it shall ensure adequate protection of the embryo". A more detailed agreement on embryo research, which will have to be approved by the council's parliamentary assembly and council of ministers, is now being discussed.

The convention forbids the creation of human embryos for research. But Britain, the only Council of Europe member state with a law specifically allowing the creation of embryos for research, will probably opt out of this provision when the convention is ratified by the UK parliament. Any country is entitled to opt out of individual clauses if its existing legislation contradicts them.

A spokeswoman for the UK Human Fertilization and Embryo Authority says that in practice most of the 20 research projects using human embryos that the authority has licensed this year use spare embryos arising from in-vitro fertilization.

The revised convention also provides greater protection than the earlier draft to individuals used for research who are unable to give their consent. This is a particularly sensitive issue in Germany with its history of Nazi abuse of concentrationcamp victims (see Nature 384, 5; 1996).

In general, says the convention, any medical intervention may only be carried out on an individual who has given free and informed consent. When an individual is not able to give such consent, the intervention must be for his or her direct benefit, and such a person must be allowed to take part in the authorization procedure "as far as possible".

The convention makes broad statements about genetics, forbidding discrimination on grounds of genetic inheritance, for example, and allowing genetic tests to be carried out only for health purposes or research related to health, and only after appropriate genetic counselling. In particular, it forbids germ therapy and the use of genetic techniques to determine the sex of a fetus, except to avoid serious sexrelated disease.

The convention must now be ratified by each member state individually. 